\title{
Konteks Sistem Sekunder Di Situs Cabean Kunti, Boyolali (Pandangan Masyarakat dan Dampaknya pada Kelestarian Situs)
}

\section{Sugeng Riyanto}

Keywords: cultural resource management, community, utilization, protection, conservation, hindu-buddha

\section{How to Cite:}

Riyanto, S. (2005). Konteks Sistem Sekunder Di Situs Cabean Kunti, Boyolali (Pandangan Masyarakat dan Dampaknya pada Kelestarian Situs). Berkala Arkeologi, 25(1), 76-89. https:/ / doi.org/10.30883/jba.v25i1.912

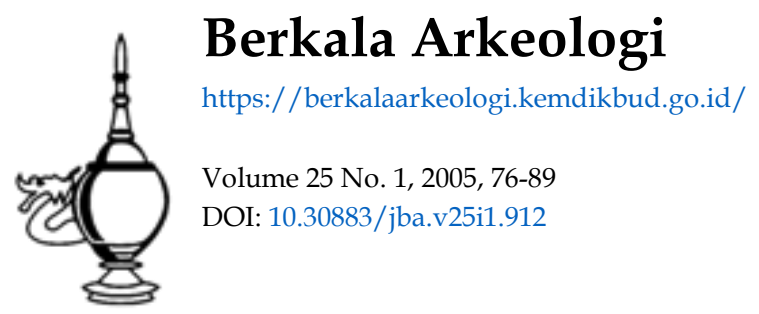

\section{cc) (†)}

This work is licensed under a Creative Commons Attribution-NonCommercial-ShareAlike 4.0 International License. 


\title{
KONTEKS SISTEM SEKUNDER \\ DI SITUS CABEAN KUNTI, BOYOLALI \\ (Pandangan Masyarakat dan Dampaknya pada Kelestarian Situs)
}

\author{
Oleh : Sugeng Riyanto
}

\section{PENDAHULUAN}

Benda Cagar Budaya (BCB) - istilah politis untuk menyebut data arkeologi - baik berupa artefak, ekofak, maupun fitur sebelum sampai pada arkeolog telah mengalami perjalanan yang panjang. M.B. Schiffer (1976), arkeolog Amerika yang mengawali studi tafonomi untuk arkeologi ini selanjutnya menjelaskan bahwa perjalanan tersebut antara lain adalah mulai dari saat dibuat, dipakai, dibuang, sampai pada saat tidak berperan lagi dalam sistem tingkah laku masyarakat masa lalu, untuk selanjutnya terbenam atau terendapkan dalam tanah, sampai akhirnya ditemukan oleh arkeolog (Mudardjito, 1982: 500). Berkenaan dengan hal itu, terdapat empat tipe proses transformasi menurut Schiffer (1976) (Mundardjito, 1982: 501-503), yaitu: 1) S - A: dari konteks sistem tingkah laku masyarakat masa lalu ke konteks arkeologi (saat ditemukan arkeolog); 2) A - S: transformasi benda budaya dari konteks arkeologi ke dalam konteks sistem tingkah laku masyarakat sekarang; 3) tipe lainnya, yaitu A - A: transformasi dari konteks arkeologi yang satu ke konteks arkeologi yang lain, seperti akibat pembangunan irigasi yang terpaksa memindahkan data arkeologi, dll. 4) S - S: dari konteks sistem yang satu ke konteks sistem yang lain, seperti peredaran kembali (artefak diubah sebagai produk baru), penggunaan sekunder (artefak digunakan dengan fungsi lain tanpa mengubahnya), dan peredaran lateral (dari satu pemakai ke pemakai lainya).

Patut dicermati apa yang dikemukakan oleh Schiffer tentang proses-proses pembentukan budaya, khususnya proses $\mathrm{A}-\mathrm{S}$ (dari konteks arkeologi ke konteks sistem sekarang). Konteks sistem di sini adalah konteks sistem yang ke-2 karena yang pertama ( proses $\mathrm{S}-\mathrm{A}$ ) adalah ketika $\mathrm{BCB}$ digunakan oleh masyarakat yang membuatnya pada masa lalu. Konteks sistem ke-2 ini diartikan sebagai BCB yang digunakan oleh masyarakat sekarang (Mundardjito, 1982: 502), baik dengan fungsi yang sama muaupun dengan fungsi yang berbeda dengan konteks sistem pertama. Konteks sistem dalam tipe transformasi inilah yang dimaksudkan dengan konteks sistem sekunder, yaitu BCB yang berlaku dalam sistem kehidupan masyarakat sekarang.

Fenomena ini menjadi menarik karena "pemanfaatan" BCB oleh masyarakat sekarang dalam batas tertentu berbeda dengan "pemanfaatan" yang dimaksudkan dalam konsep Cultural Resource Management (CRM). Yang pertama barangkali 
dapat dikategorikan sebagai pemanfaatan tradisional, sedangkan yang ke-2 (CRM) adalah pemanfaatan terencana (managed) dengan fungsi yang lebih luas, misalnya sebagai obyek wisata (ekonomik), pendidikan (ideologik), atau untuk pengembangan ilmu (akademik).

Contoh fenomena seperti ini (konteks sistem sekunder secara tradisional) yang cukup menarik adalah yang terjadi di Situs Cabean Kunti, Boyolali. Situs yang berupa beberapa (candi) petirtaan masa klasik, sekitar abad IX - X M ini adalah salah satu sumber daya lingkungan yang dimanfaatkan oleh masyarakat setempat untuk berbagai keperluan hidup keseharian. Keberadaannya jelas sangat menguntungkan, karena mereka memanfaatkannya secara gratis, bahkan tanpa membuatnya. Hal ini barangkali bisa dianalogikan dengan terbukanya akses ke sumberdaya sehingga berbagai cara yang ditempuh penduduk miskin untuk mempertahankan kehidupannya (Kutanegara, 2000: 322), termasuk penduduk sekitar Situs Cabean Kunti. Namun ternyata mereka tidak hanya mengeksploitasi sumber daya ini, karena selain kegiatan keseharian seperti mandi, cuci, masak, mereka juga secara periodik mengadakan berbagai kegiatan sakral, seperti upacara sesaji, bersih desa, nguras lepen, dsb.

Situs petirtaan Cabean Kunti adalah salah satu sumber daya dan bagian dari lingkungan hidup bagi masyarakat setempat. Sementara itu, paling tidak ada tiga kemungkinan berkaitan dengan kualitas lingkungan akibat pengaruh manusia, yaitu deteriosasi, tetap lestari, atau perbaikan (Soedjiman, dkk., 1992: 167). Berkaitan dengan gambaran tersebut maka muncul persoalan, yaitu:

- Sebenarnya, bagaimanakah pandangan masyarakat terhadap kedudukan dan peran situs?

- Lalu, bagaimana pengaruhnya pada kelestarian situs ?

\section{POTRET SITUS DAN KONTEKS SISTEM PRIMER}

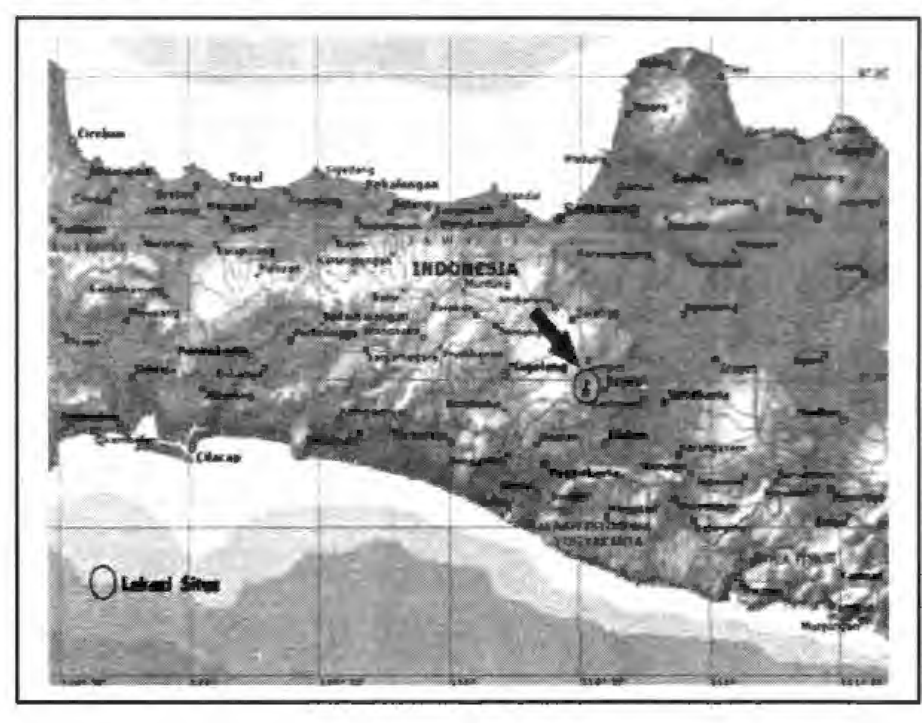

Secara administrasi, situs Cabean Kunti terletak di Dusun Kunti dan Dusun Balong Margomulyo, Desa Cabean Kunti, Kecamatan Cepogo, Kabupaten Boyolali, Provinsi Jawa Tengah. Walaupun dalam skala yang kecil, tetapi situs ini termasuk dalam ketegori situs kawasan karena terdiri atas tujuh bangunan pemandian yang terbuat dari batu andesit. Keletakan masing-masing 
bangunan adalah linier berdasarkan aliran sungai dengan orientasi aliran timurlaut.

Penduduk setempat mengenal masing-masing bangunan berdasarkan nama yang diberikan oleh generasi terdahulu, dan tidak diketahui secara pasti kapan namanama tersebut mulai dikenal. Ketujuh bangunan tersebut (diurutkan dari barat) adalah (Lelono, 2000: 11-13):

1. Sendang Jangkang: Sebagian besar batunya sudah hilang terbawa arus sungai sehingga oleh penduduk diberi tanggul dari batu dan semen.

2. Sendang Pertapan: berjarak sekitar 75 meter dari bangunan pertama dan bentuknya masih agak utuh dengan ukuran $150 \times 470 \times 30 \mathrm{~cm}$. Aspek estetis masih tampak kuat terutama pada bagian pagar berupa kemuncak dan antefiks.

3. Sendang Lereban: berjarak sekitar 10 dari bangunan ke-2 dan dapat dikatakan paling lengkap dengan ukuran bangunan $165 \times 468 \times 95 \mathrm{~cm}$. Selain paling lengkap, unsur estetis juga paling kuat terlihat, yaitu selain beberapa unsur bangunannya yang dekoratif juga kehadiran relief-relief pada dinding pagar yang cukup beragam mulai dari binatang hingga manusia dalam berbagai adegan.

4. Sendang Lanangan: bejarak sekitar $60 \mathrm{~m}$ dari bangunan ke-3. meskipu kondisinya nyaris sama dengan bangunan pertama, namun ukurannya masih dapat diperkirakan, yaitu $230 \times 400 \mathrm{~cm}$.

5. Sendang Panguripan: berada sekitar $10 \mathrm{~m}$ di utara bangunan ke-4. Ukurannya lebih kecil, yaitu $97 \times 127 \mathrm{~cm}$.

6. Sendang Keputren: terletak sekitar $10 \mathrm{~m}$ di sebelah timur dari bangunan ke5. Kondisi bangunan masih agak utuh dengan ukuran $155 \times 468 \times 130 \mathrm{~cm}$. Meskipun aspek estetik tampak pada beberapa unsur bangunannya, namun tidak dijumpai adanya pahatan relief pada dinding pagarnya.

7. Sendang Kesucian: berjarak sekitar $50 \mathrm{~m}$ arah timur dari bangunan ke-6. Bangunan yang berukuran $174 \times 518 \times 55 \mathrm{~cm}$ tampaknya paling utuh dibandingkan dengan 6 bangunan lainnya. Namun demikian, relief yang dipahakan pada dinding pagar sebatas pada gambaran dekoratif dan bukan figurine.

\footnotetext{
* dalam jarak sekitar 1,5 km arah timur, terdapat situs petirtaan lain yang oleh penduduk disebut Sumur Songo. Bangunan ini meskipun jumlahnya lebih banyak (sembilan) namun lebih sederhana dan berasal dari abad VIII - IX M (Soeroso, 1982: 98). Untuk mempertahankan fokus, situs ini sengaja tidak dibahas dalam makalah ini.
} 


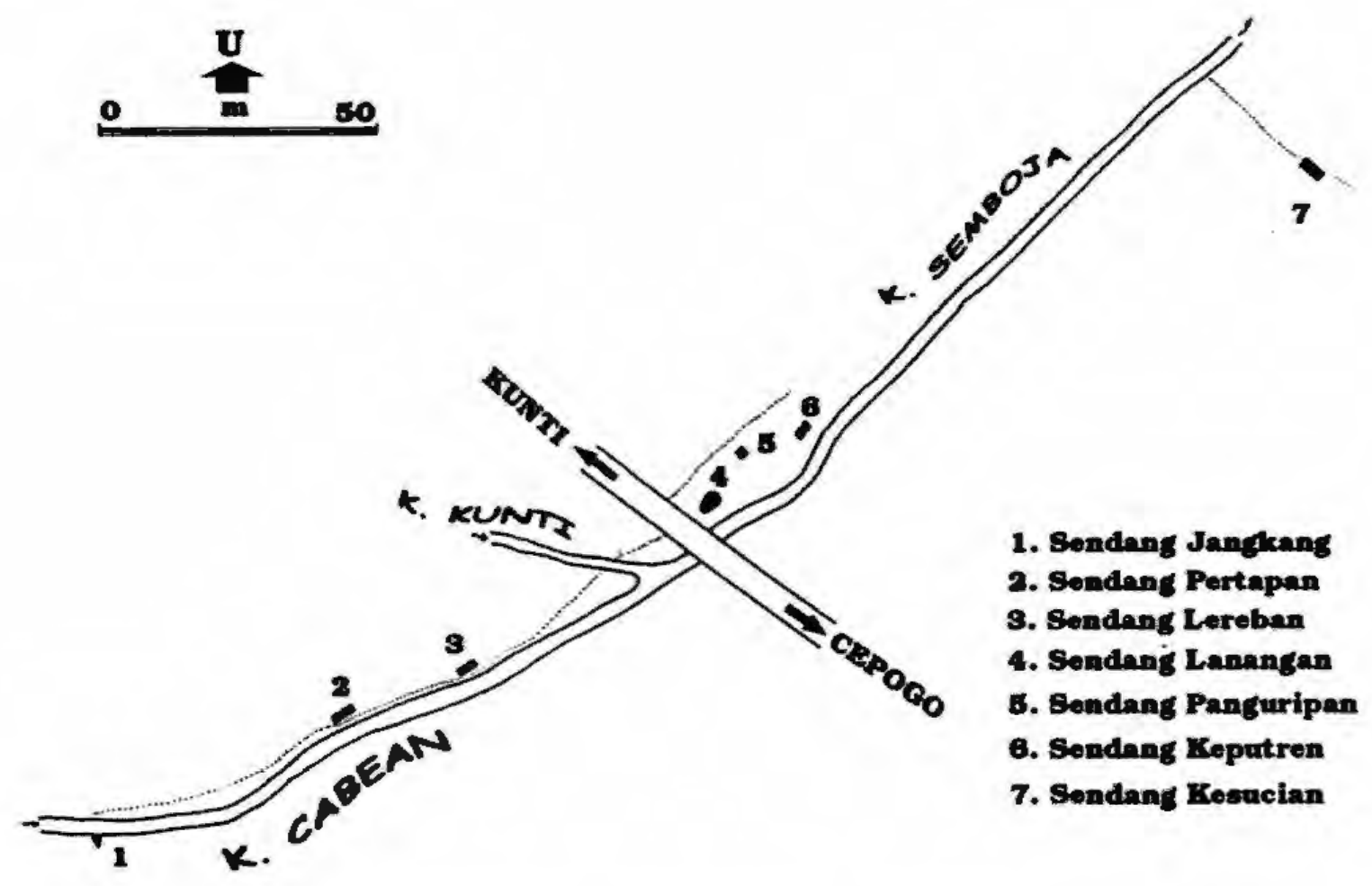

Tentu ada alasannya mengapa bangunan-bangunan ini disebut pemandian suci atau petirtaan bagi masyarakat Jawa Kuna. Hal ini tentu saja berkaitan dengan konsep religius yang hidup pada masa itu dan juga dapat dianalogikan pada situs sejenis di tempat lain. Sementara itu, pengertian umum tirtha adalah sacred tank or bathing place sehingga bathing in sacred places has a ritual meaning (Libert, 1976: 298). Secara fisik, tirtha bisa berupa apa saja yang dianggap sebagai sumber air; di India sendiri sungai kecil yang tidak terkenal juga dianggap sebagai tempat suci atau tirtha (Salmon, 1984: 328).

Masyarakat Jawa Kuna memang telah mengenal tatanan adat yang kuat tentang tirtha yang dianggap suci bukan hanya karena berasal dari tempat yang suci tetapi karena unsur yang terkandung di dalam tirtha itu sendiri (Soeroso, 1982: 32). Air dianggap sebagai awal kehidupan sekaligus sebagai sumber kehidupan manusia sehingga harus diperlakukan secara khusus. Keberadaan bangunan ini jelas didorong oleh pandangan tersebut sehingga muncul kebutuhan akan petirtaan untuk bathing in sacred places has a ritual meaning.

Sebagai konteks sistem primer, masyarakat pada waktu itu tentu saja memiliki pandangan yang tersendiri tentang kedudukan dan peran petirtaan ini. Makna sebagai cermin dari pandangan tersebut dapat dilihat antara lain berdasarkan jumlah bangunan dan penggambaran relief yang dipahatkan pada dinding bangunan seperti diuraikan berikut ini. 
Jumlah bangunan petirtaan yang tujuh berkaitan dengan angka magis yang dikenal luas di dunia. Khususnya berkaitan dengan doktrin Brahma, angka tujuh dianggap memiliki nilai magis terutama karena ada pandangan bahwa jagad raya terdiri atas Jambudwipa, sebuah benua yang bebentuk lingkaran dan dikelilingi oleh tujuh benua dan tujuh samudra yang juga berbentuk lingkaran. Sementara itu, di India juga dikenal adanya tujuh sungai yang dianggap suci dan bernilai magis, yaitu Sungai Gangga, Yamuna, Sindu, Kauciki, Saraswati, Wipaca, dan Sarayu (Soeroso, 1982: 80). Meskipun belum didukung dengan data yang lebih kuat, misalnya prasasti atau naskah, penjelasan makna religius bangunan petirtaan Cabean Kunti pada masa lalu (konteks sistem primer) antara lain memang terletak pada jumlah bangunan yang tujuh. Sementara itu keletakannya yang mengikuti aliran air tampaknya lebih bermakna teknis, yaitu berkaitan dengan pasokan air.

Relief yang dipahatkan pada bangunan ke-3 (Sendang Lereban) secara garis besar dapat dibedakan dalam dua kelompok, yaitu berupa sosok binatang dan manusia. Hasil identifikasi terhadap relief ini menunjukan bahwa adegan yang digambarkan merupakan bagian dari beberapa cerita (Soeroso, 1982: 84-94). Khusus relief binatang, berhasil diidentifikasi paling tidak empat cerita, yaitu: 1) cerita tentang bangau dan ikan; 2) gagak, pohon kepuh, dan ular naga; 3) burung betet dan raja; 4) burung merak dan Dewa Kama. Sementara itu, relief yang menggambarkan figur manusia merupakan gambaran dari dua kegiatan, yaitu: 1) kegiatan sesajian dan 2) kegiatan perjudian.

Secara umum relief ini mengandung ajaran moral dengan tujuan agar mencapai kebahagian hidup di dunia dan setelah mati. Agaknya, selain sebagai tempat suci, bangunan petirtaan ini sekaligus juga dijadikan sebagai media untuk menyebarkan ajaran moral, khususnya kepada setiap orang yang "bathing in sacred places" sehinga "has a ritual meaning" secara lebih sempurna. Inilah gambaran singkat tentang kedudukan dan peran situs Cabean Kunti dalam konteks sistem primer.

\section{CABEAN KUNTI DALAM KONTEKS SISTEM SEKUNDER}

Masyarakat diartikan sebagai sekumpulan orang yang terorganisir, saling berbagi tempat hidup, saling tergantung satu sama lain, dan mempunyai tujuan agar dapat bertahan serta demi kesejahteraan (Harris, 1997: 88). Penduduk sekitar situs Cabean Kunti, sebagai sebuah organisasi, secara umum tidak dapat dikatakan sebagai masyarakat yang sejahtera, dan dalam batas tertentu sangat tergantung pada sumber daya lingkungan di sekitarnya. Ada pandangan bahwa penyebab munculnya kemiskinan adalah keterbatasan akses penduduk terhadap sumber daya (Kutanegara, 2000: 314). Demikian pula dengan mereka, sumber daya produktif, khususnya lahan pertanian, sudah sangat terbatas yang dapat dikelola sehingga sumber daya lain, yang tidak produktif secara ekonomik, dimanfaatkan secara maksimal: termasuk situs petirtaan yang menyediakan kebutuhan air 
untuk berbagai keperluan. Pemanfaatan ini dalam batas tertentu sebenamya merupakan salah satu wujud adaptasi. Dalam kaitannya dengan hal ini, Kaplan dan Albert A. Manners (2002: 116) menjelaskan tentang orientasi ekologibudaya yang membawa pada wawasan bahwa manusia sebagai suatu spesies, seperti juga mahluk hidup lainnya, menghadapi keharusan untuk beradaptasi dengan lingkungan dan mengeksploitasinya.

Namun menurut pandangan masyarakat setempat, situs ini pun ternyata ada "yang memiliki", yaitu ibunda para Pandawa (Dewi Kunti), sehingga ada aturanaturan yang harus dipatuhi untuk dapat mengaksesnya. Pandangan ini sekaligus sebagai interpretasi dan penjelasan terhadap kedudukan situs, yang tentu saja berbeda dengan eksplanasi arkeolog. Dalam arkeologi modern ("arkeologi pasca prosesual") interpretasi dan pandangan semacam ini adalah penting karena sudah semestinya arkeologi dikembangkan lebih terbuka bagi pandangan atau tafsiran versi masyarakat luas dan membiarkan masyarakat memahami sumber daya budaya menurut caranya sendiri, tidak harus mengikuti versi arkeologi (Tanudirjo, 1998: 16).

Dengan demikian tampak ada dua aspek yang menonjol pada hubungan antara masyarakat Cabean Kunti sekarang dengan situs petirtaan (konteks sistem sekunder), yaitu: aspek praktis dan aspek religius. Uraian mengenai kedua aspek tersebut adalah sebagai berikut.

\section{Aspek Praktis}

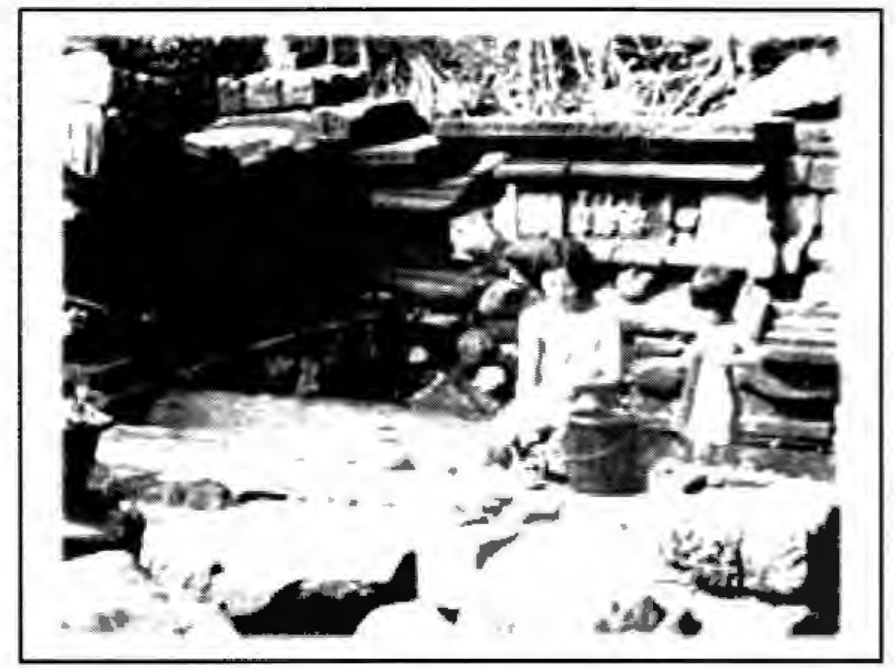

Sebagai sumber air, masyarakat sudah begitu menyatu dengan situs mi karena secara rutin, paling sedikit dua kali sehari, mereka mengunjunginya berkaitan dengan keperluan keseharian. Sampai dengan tahun 1980-an, sebagai sumber air, situs ini paling tidak dimanfaatkan oleh penduduk di 10 dusun sekitarnya (Soeroso, 1982: 31). Kegiatan keseharian (aspek praktis) yang di sendang antara lain adalah mandi dan cuci (pakaian dan perabot rumah tangga) di sendang Lereban dan Kaputren. Sementara itu, kebutuhan air untuk memasak (termasuk minum) kaum wanita mengambil dari Sendang Paguripan karena airnya dianggap lebih jernih dan bersih (Lelono, 2000: 25). 


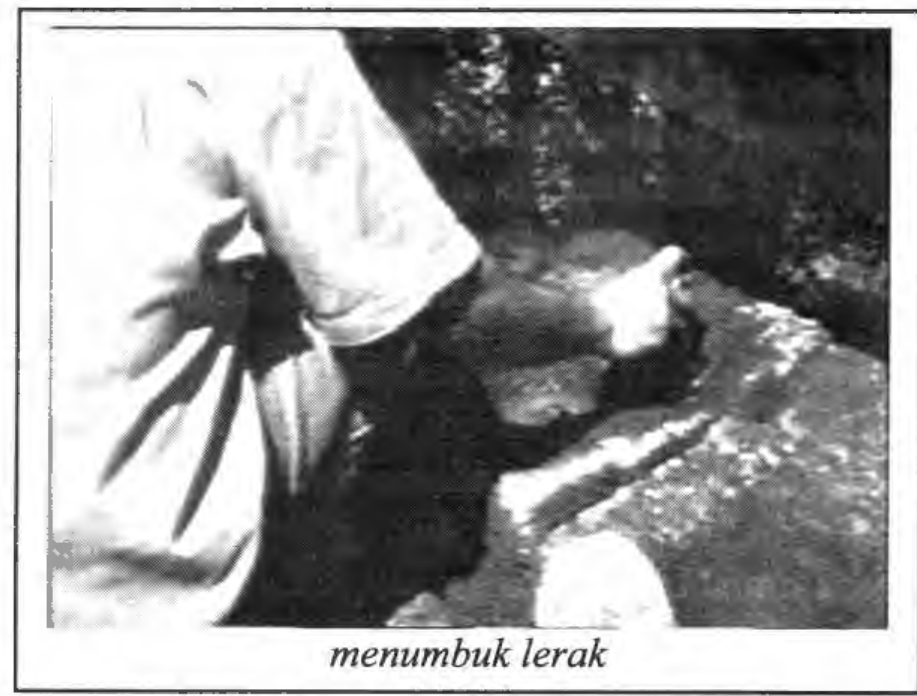
batik. Diyakini bahwa cara mencuci seperti ini akan berefek pada ketahanan warna dan lukisan batik. Bekas aktivitas penumbukan lerak ini berupa sejumlah besar lubang pada batu-batu bangunan sendang, khususnya di bagian tepiannya.

\section{Aspek Religius}

Aspek religius barangkali berangkat dari "eksplanasi" yang diberikan kepada situs bahwa bangunan petirtaan ini berkaitan dengan Dewi Kunti. "teori" versi masyarakat ini dikemas dalam dongeng atau legenda. Masyarakat sekitar Cabean Kunti memang percaya bahwa di petirtaan tersebut ada "penunggu", yaitu Dewi Kunti, yang dalam pewayangan adalah tokoh ibu para Pandawa. Berkaitan dengan hal ini ada beberapa larangan antara lain dilarang nanggap wayang dengan lakon Dewi Kunti; dilarang mengenakan kain, iket, dan kemben yang berwarna hijau, dan setiap malam Selasa Kliwon diadakan kegiatan sesajian yang ditujukan kepada Dewi Kunti (Soeroso, 1982: 16).

Secara ringkas, legenda tersebut diuraikan oleh Hari Lelono (2000: 30) dan dalam kutipan di bawah ini mengalami penyesuaian redaksional sebagai berikut.

... Cabean Kunti adalah sebuah tempat yang sangat subur, indah, terletak di tengah hutan dengan air yang melimpah karena dialiri oleh beberapa sungai, yaitu Sungai Lereb dan Kunti yang akhirnya menyatu menjadi Sungai Semboja.

Pada saat Dewi Kunti masih muda, ia dicintai dan hendak dipinang oleh seorang perjaka yang sakti bernama Jaka Bandung, tetapi Dewi Kunti menolak dan terus menghindar. Dengan kesaktiannya, Jaka Bandung selalu dapat menemukan tempat persembuniannya. Setelah kepayahan berlari dan 
bersembunyi tetapi selalu dapat ditemukan, akhirnya Dewi Kunti menyerah dan bersedia dipinang oleh Jaka Bandung. Penyerahan ini disertai syarat agar dibuatkan tujuh sendang dengan sembilan sumur yang dibangun tanpa tenaga manusia (tanpa kamunangsan) dalam waktu satu hari satu malam.

Syarat ini diterima Jaka Bandung dan dengan kesaktiannya tujuh buah sendang dapat diselesaikan dengan baik dengan bantuan para mahluk halus (dedemit dan genderuwo). Sekarang tinggal selangkah lagi, yaitu sembilan buah sumur (sumur songo) yang mestinya lebih mudah. Akan tetapi, sebelum Jaka Bandung menyelesaikan pekerjaannya, Dewi Kunti membangunkan para wanita dan disuruh membunyikan tetabuhan hingga para dedemit dan genderuwo ketakutan mengira matahari sudah terbit. Tentu saja mereka tidak bisa meneruskan pekerjaan sehingga syarat tujuh buah sumur gagal dipenuhi.

Jaka Bandung sangat marah karena mengetahui kegagalannya diakibatkan oleh akal Dewi Kunti yang membangunkan para wanita dan memerintahkan memukul tetabuhan sebelum fajar. Dalam kemarahannya Jaka Bandung berkata bahwa dia membangun candi (pemandian) agar daerah ini dikenang, dikenal, dan ramai di kemudian hari. Selain itu dia juga mengutuk Dewi Kunti tidak akan memperoleh suami, termasuk seluruh wanita yang ada di tempat ini. Setiap lelaki yang datang akan merasa enggan untuk meminang wanita dari dusun ini ...

Dengan penjelasan versi masyarakat ini, maka Situs Cabean Kunti memang memiliki nilai spiritual dan emosional bagi penduduk sekitar. Hal semacam ini sebenarnya bukan fenomena yang luar biasa, khususnya di Jawa. Banyak desa di Jawa yang masih memiliki pepohonan besar baik di tengah atau pinggir desa dan seringkali terdapat sendang, mata air, atau telaga di bawahnya. Tidak jarang pula tempat-tempat ini berupa tinggalan purbakala seperti patung dewa, menhir, prasasti, candi, dsb. yang diyakini sebagai tempat keramat dan dijaga oleh mahluk halus (Soehardi, 2000: 330). Dalam batas tertentu, penjelasan ini pada gilirannya membentuk sebagai sebuah kepercayaan yang mengandung keyakinan. Selain mengandung keyakinan tentang sifat-sifat Tuhan, sebagai salah satu komponen dari sistem religi, sistem kepercayaan juga mengandung keyakinan tentang wujud alam gaib, dewa-dewa, dan mahluk halus yang mendiami alam gaib. Kepercayaan ini selanjutnya diekspresikan dalam sistem upacara religius yang antara lain bertujuan untuk mencari hubungan dengan Tuhan, dewa, atau pun mahluk halus tadi (Herususato, 1984: 27).

Berkaitan dengan hal tersebut maka tidak mengherankan jika penduduk sekitar situs sampai saat ini masih melaksanakan kegiatan ritual berkaitan dengan keyakinan mereka akan Dewi Kunti. Upacara sakral ini dilaksanakan secara perorangan dan secara masal (Lelono, 2000: 26). 


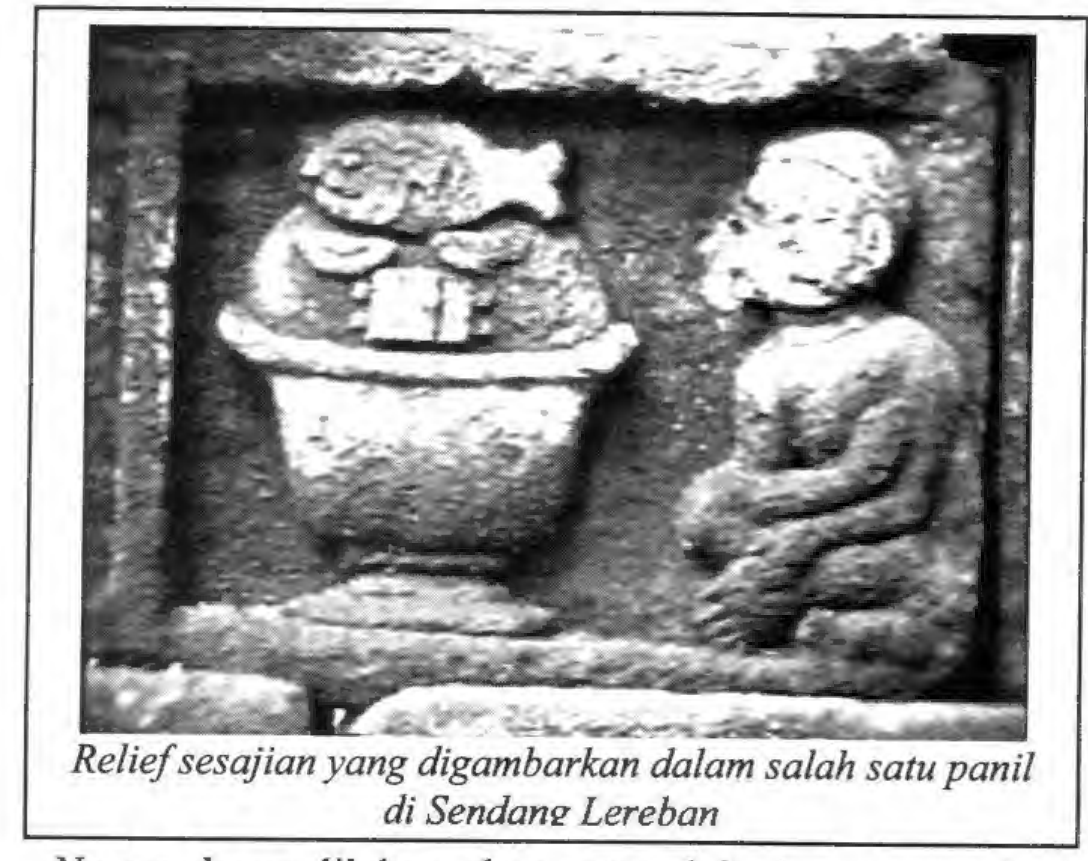

Kegiatan ritual yang dilaksanakan secara perorangan antara lain disebut dengan upacara ngirim lepen sebagai "tuntutan" ketika seseorang memiliki hajat tertentu, seperti kehamilan, kelahiran, sunatan, dan perkawinan; atau mempunyai niat tertentu seperti memiliki kekuatan, kesehatan, tambah rejeki, keselamatan, dsb.

Nguras lepen dilaksanakan antara lain dengan memberi sesajian di tempat tertentu berupa makanan tertentu, bunga tertentu, dan benda tertentu lainnya. Beberapa upacara bahkan menyaratkan untuk berendam di dalam sendang pada malam hari.

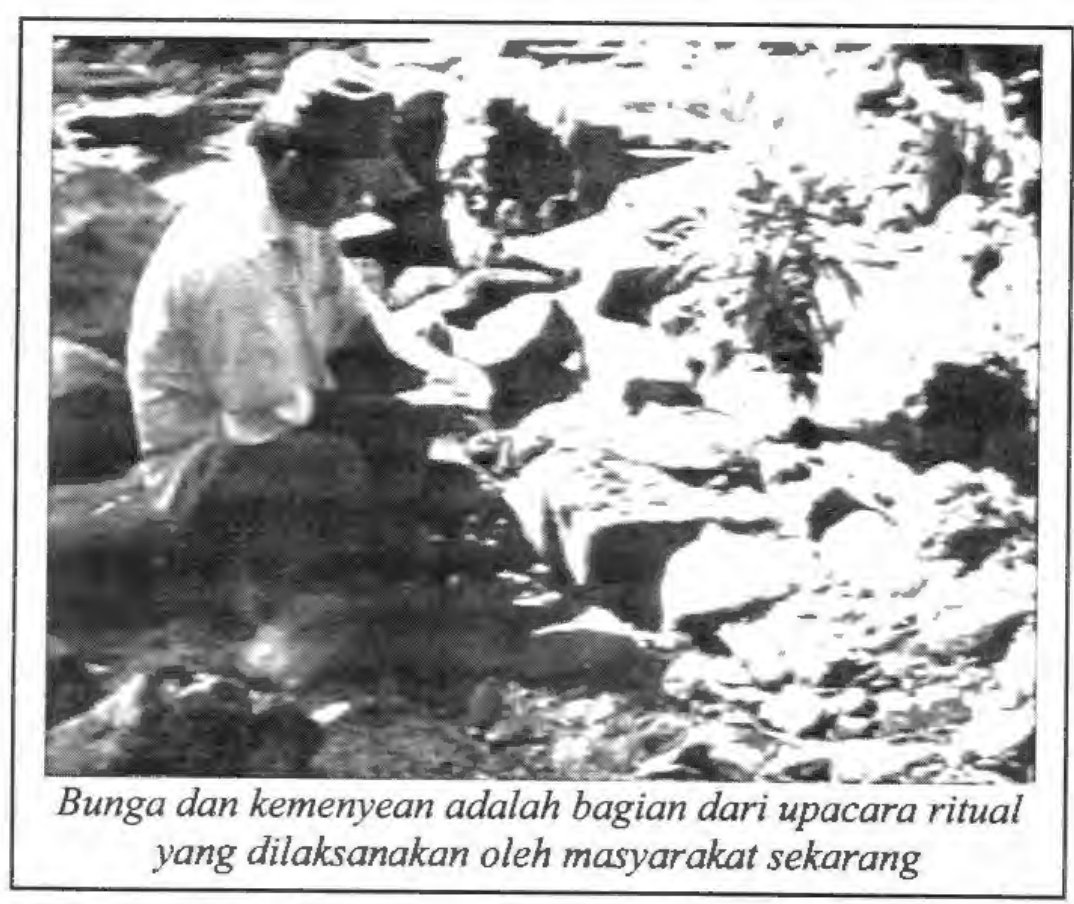

merawatnya. Lelono (2000) menambahkan bahwa
Secara massal, kegiatan religius yang tetap dijaga adalah nguras lepen yang bermakna dasar membersihkan sungai dan lingkungannya sebagai sumber air, termasuk sendang. Makna ini sekaligus memberi gambaran kedekatan masyarakat dengan situs ini; mereka tidak saja tergantung pada sendang sebagai sumber air, tetapi juga merasa memiliki sehingga merasa harus dilaksanakan oleh dua kelompok, yaitu 
1. masyarakat Dusun Cabean dan Dusun Kunti yang melaksanakan pada siang hari dan memberi sesaji (nasi golong) dan doa setelah acara pembersihan sendang.

2. masyarakat Dusun Balongan yang melakukan doa pada malam hari, khususnya pada malam Selasa Kliwon, dan setelah subuh dilanjutkan dengan acara pembersihan sendang dan Sungai Semboja.

\section{EFEK PADA KELESTARIAN SITUS}

Keberadaan situs Cabean Kunti dalam konteks sistem sekunder pada akhirnya memang paling tidak melibatkan dua pihak, yaitu arkeolog dan masyarakat setempat dengan muatan kepentingan masing-masing. Arkeolog dalam batas tertentu "menginginkan" agar setiap situs menjadi aset yang dilindungi secara hukum (UU No. 5 Tahun 1992); di pihak lain, masyarakat menginginkan (dengan didasari interpretasi versi mereka) agar sumber air, yang ternyata BCB, tersebut dapat diakses demi kelangsungan hidup mereka.

Jika dicermati, kegiatan keseharian masyarakat setempat sebenarnya tidak "mengganggu" keberadaan situs karena yang menjadi tujuan utama mereka adalah air itu lah dan bukan bangunan petirtaan atau bagian-bagiannya secara fisik. Justru karena merasa berkepentingan dengan situs ini sebagai sumber air, maka dalam batas tertentu dan dengan cara tertentu pula mereka mengupayakan kelestariannya.

Salah satu aspek yang dapat dikatakan sebagai upaya kelestarian situs oleh masyarakat adalah penjelasan bahwa sendang ini merupakan tinggalan Dewi Kunti dan sampai sekarang tetap dijaga olehnya atau oleh mahluk gaib lainnya. Oleh karena itu mereka mengadakan kegiatan ritual baik secara berkala maupun setiap saat dipandang perlu. Kepercayaan tehadap mahluk halus yang menjaga tempat keramat - termasuk petirtaan Cabean Kunti - meskipun tidak masuk akal namun sebenarnya mengandung pesan-pesan yang tersembunyi, yaitu: jangan merusak lingkungan atau menguras alam secara berlebihan. Berkaitan dengan tinggalan arkeologi, ada larangan untuk merusak pundhen, termasuk memindahkan benda purbakala (Soehardi, 2000: 330). Hal ini ternyata selaras dengan UU RI No. 5 Tahun 1992 tentang Benda Cagar Budaya yang berbunyi (Anonim, 1994: 16): "Barang siapa dengan sengaja merusak benda cagar budaya dan situs ... atau membawa, memindahkan, mengambil ... tanpa izin dari Pemerintah ... dipidana dengan pidana penjara selama-lamanya 10 (sepuluh) tahun dan/atau denda setinggi-tingginya Rp 100.000.000,- (seratus juta rupiah).

Jika enkulturasi diartikan sebagai eara-cara hidup yang diwariskan melalui proses belajar dari generasi ke generasi (Harris, 1997: 88) maka "cara pelestarian" menurut masyarakat sekitar Situs Cabean Kunti merupakan salah satu di antaranya. Memang tidak ada satu tokoh pun yang bisa menjelaskan sejak kapan 
pandangan dan cara ritual tersebut dilakukan. Mereka hanya berani menyatakan bahwa hal tersebut dipelajari dari orang tua atau orang yang dituakan. Artinya, Situs Cabean Kunti masih dapat dilihat hingga sekarang (meskipun tidak utuh lagi) salah satunya barangkali justru karena dimanfaatkan sebagai sumber air sejak waktu yang sudah sangat lama.

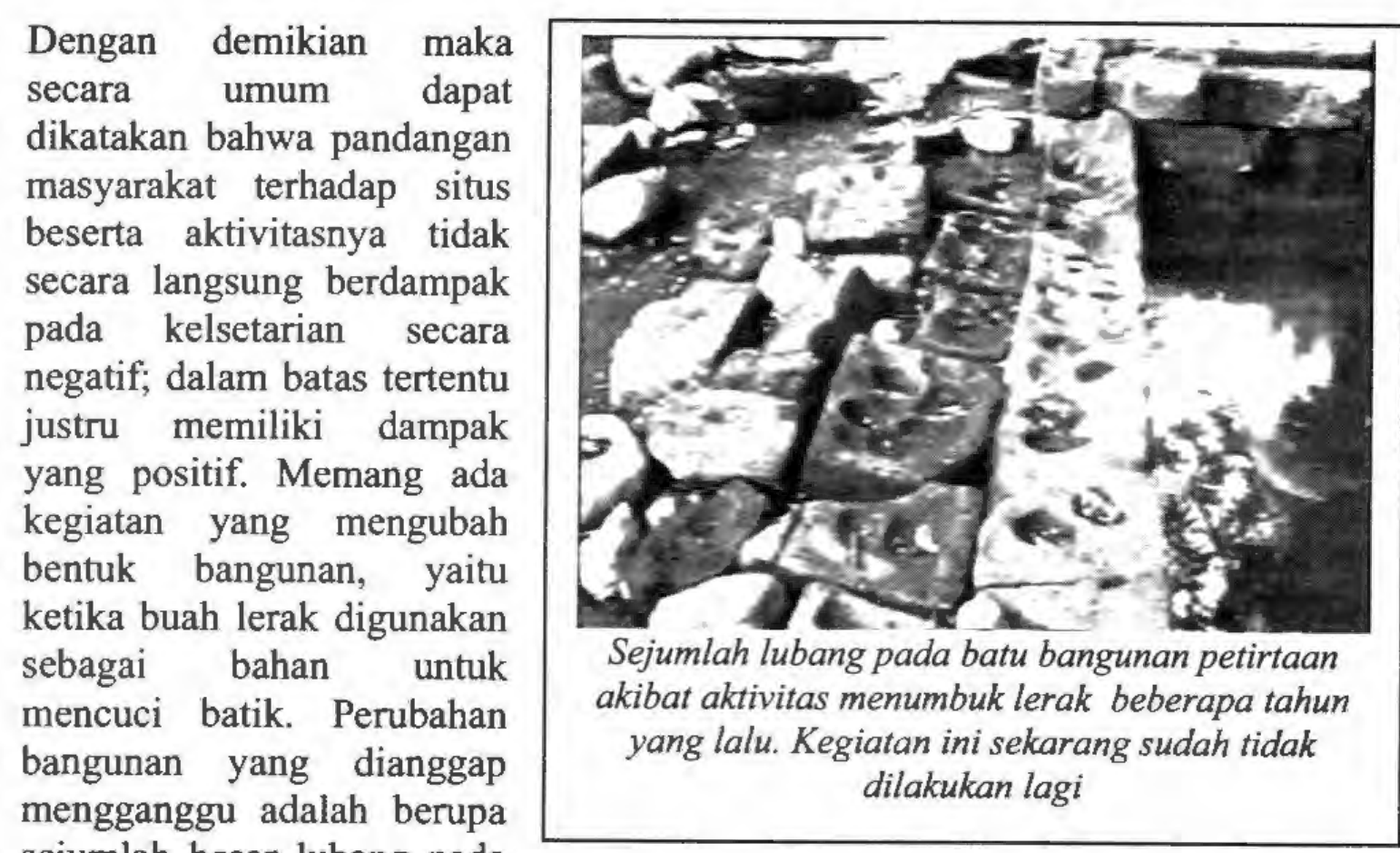
sejumlah besar lubang pada sebagian besar batu sebagai akibat kegiatan menumbuk buah lerak tadi. Keberadaan lubang pada bahan utama bangunan secara arkeologis jelas tidak bisa diterima karena secara akademik berkaitan dengan perubahan data; namun kegiatan menumbuk lerak ini sekarang sudah tidak pernah dilakukan lagi, setidaknya tidak di sekitar bangunan.

Upaya pelestarian benda cagar budaya haruslah dipandang sebagai pengelolan sumberdaya secara bijak dengan mempertimbangkan kepentingan banyak pihak yang kadangkala saling bertentangan (Tanudirjo, 2003: xvii). Pihak yang berkepentingan dengan Situs Cabean Kunti hingga saat ini memang tergolong belum terlalu kompleks dan masih terbatas pada (sedikitnya) tiga kelompok, yaitu arkeolog, masyarakat yang memanfaatkannya sebagai sumber air, dan masyarakat yang menjadikan situs ini sebagai tempat untuk melakukan kegiatan ritual.

Sebanarnya ada pihak lain yang seharusnya lebih peduli, yaitu Pemerintah (Pemda dan Pariwisata) yang diperkirakan sudah ancang-ancang untuk "campur tangan" dalam pengelolaan situs ini. Dugaan ini begitu kuat ketika secara resmi Pemda Jawa Tengah meluncurkan konsep wisata jalur SSB (Solo - Selo - Borobudur) 
dan situs ini terletak hanya beberapa kilometer dari jalur tengah (Selo) yang memang dikembangkan sebagai kawasan wisata alam dan pedesaan.

\section{PENUTUP}

Perubahan fungsi petirtaan Cabean Kunti dari primer (konteks sistem masyarakat pendukung) ke konteks sistem sekunder (konteks sistem sekarang) memang terjadi tetapi tidak secara linear; tidak ada kaitan antara masyarakat Jawa Kuna abad IX/X dengan masyarakat Cabean Kunti sekarang. Penjelasan sekarang yang dikaitkan dengan Dewi Kunti agaknya diberikan setelah petirtaan ini menjadi konteks arkeologi. Namun demikian, dalam konteks sistem sekunder ini terjadi hubungan resiprokal dan saling meguntungkan. Di satu sisi masyarakat membutuhkan keberadaan situs sebagai sumber air dan sebagai tempat untuk melakukan kegiatan ritual dan di sisi lain kelestarian situs dapat terjaga secara alamiah. Sebagai bagian dari kebudayaan, apa yang dilakukan masyarakat adalah tidak tanpa alasan karena mereka mempelajarinya dari generasi sebelumnya. Kebudayaan memang merupakan cara berlaku yang dipelajari dan kebudayaan tidak tergantung pada transmisi biologis atau pewarisan melalui unsur genetis (Ember \& Melvin Ember, 1990: 18).

Jika Situs Cabean Kunti dianggap sebagai bagian dari lingkungan, maka pengaruh pandangan dan aktivitas masyarakat setempat adalah positif. Pengaruh manusia terhadap lingkungannya dapat mengakibatkan paling tidak tiga kemungkinan akan kualitas lingkungan, yaitu: deteriosasi, tetap lestari, atau justru memperbaiki (Soedjiman, 1992: 167). Dengan demikian maka dalam hal ini pengaruh masyarakat terhadap situs adalah tetap letari.

Hal yang justru perlu "diwaspadai" adalah kemungkinan situs ini menjadi bagian dari konsep pengembangan wisata Solo - Selo - Borobudur (SSB) karena letak dan karakternya yang potensial. Dari segi akses, situs ini relatif dekat dengan jalan raya jalur tengah (Selo); dari segi potensi, kawasan ini memiliki atraksi alam, atraksi wisata desa, dan situs petirtaan sekaligus (unsur tangible dan intangible ada di sana). Tampaknya potensi ini memang besar dan "siap kemas", namun selain pengaruhnya terhadap situs, dampak pada perubahan perilaku masyarakat juga harus diperhitungkan. Perubahan yang berdampak pada kehidupan masyarakat dapat dibedakan menjadi dua, yaitu (Merton, 1968: 115; Sulistyanto, 2003: 140): a) perubahan yang berfungsi manifes atau perubahan yang disadari atau bahkan di harapkan, dan b) perubahan yang befungsi laten atau perubahan yang dampaknya tidak disadari atau bahkan tidak diharapkan terjadi.

Ketenangan Situs Cabean Kunti dan masyarakat setempat sebagai pelaku konteks sistem sekunder yang hingga kini terjaga agaknya segera akan menjadi salah satu sumber konflik baru. Oleh karena itu: "sedia payung sebelum hujan" barangkali 
menjadi pepatah yang tepat untuk menghadapinya. Paling tidak ada dua hal yang perlu dipersiapkan yaitu 1) pengelolaan konflik yang pasti akan muncul; dan 2) memberdayakan masyarakat sekitar dalam pengembangan kawasan ini sebagai bagian dari konsep pengembangan pariwisata SSB.

\section{DAFTAR PUSTAKA}

Ember, Carol L. \& Melvin Ember. 1990. "Konsep Kebudayaan”. Dalam T.O. Thromi (ed.). Pokok-pokok Antropologi Budaya. Cetakan ke-enam. PT Gramedia, Jakarta

Harris, Marvin. 1997. Culture, People, Nature. An Introduction to General Anthropology. $7^{\text {th }}$ edition. Addison Wesley Longman, Inc, New York.

Herususanto, Budiono. 1984. Simbolisme dalam Budaya Jawa. PT Hanindita Offset, Yogyakarta.

Kaplan, David \& Albert A. Manners. 2002. Teori Budaya. Terjemahan Landung Simatupang. Cetakan III. Pustaka Pelajar, Yogyakarta.

Kutanegara, Pande Made. 2000. "Akses terhadap Sumber Daya dan Kemiskinan di Pedesaaan Jawa: Kasus Desa Sriharjo, Yogyakarta". Humaniora. Vol, XII, No.3/2000: 313-323.

Lelono, T.M. Hari. 2000. Laporan Penelitian Arkeologi Perilaku Masyarakat Jawa dalam Pemanfaatan Sumber Air (Studi Kasus Kegiatan Ritual di Situs Candi Petirtaan). Balai Arkeologi Yogyakarta. Tidak terbit.

Libert, Gosta. 1976. Iconographic Dictionary of the Hinduism - Buddhism Jainism. E.J. Brill, Leiden.

Merton, Robert. 1968. "Manifest and Latent Fungsions". On Teoritical Sociology. The Free Press, New York.

Mundardjito. 1982. "Pandangan Tafonomi dalam Arkeologi: Penilaian Kembali atas Teori dan Metode". Dalam Proceeding PIA II: 497 - 509. 
Salmon, Richard. 1984. "Traditional Hindu Concept of Tirtha and Yatra as Reflected in Smtri Literature". Dalam Pranabandana Jash (ed.) Row \& Chawdhury: $327-332$.

Schiffer, M.B. 1976. Behavior Archaeology. Academic Press,New York.

Soedjiman, R. Dkk. 1992. Pengantar Ekologi. PT Remaja Rosdakarya, Bandung.

Soehardi. 2000. "Budaya Arif Lingkungan dan Solidaritas Sosial: Konteks Konservasi Sumber Daya Nonhayati". Humaniora. Vol. XII, No.3: 324332.

Soeroso. 1982. Fungsi Petirtaan Cabean Kunti bagi Masyarakat Jawa Kuna. Skripsi, Fakultas Sastra UGM, Yogyakarta.

Sulistyanto, Bambang. 2003. Balung Buto, Warisan Budaya Dunia dalam Perspektif Masyarakat Sangiran. Kunci Ilmu, Yogyakarta.

Tanudirjo, Daud Aris. 1998. "Cultural Resource Management sebagai Manajemen Konflik". Dalam Artefak. No 19: 14-18.

2003. "Benda Cagar Budaya Milik Siapa?". Pengantar dalam Bambang Sulisyanto, Balung Buto, Warisan Budaya Dunia dalam Perspektif Masyarakat Sangiran. Kunci Ilmu, Yogyakarta. 